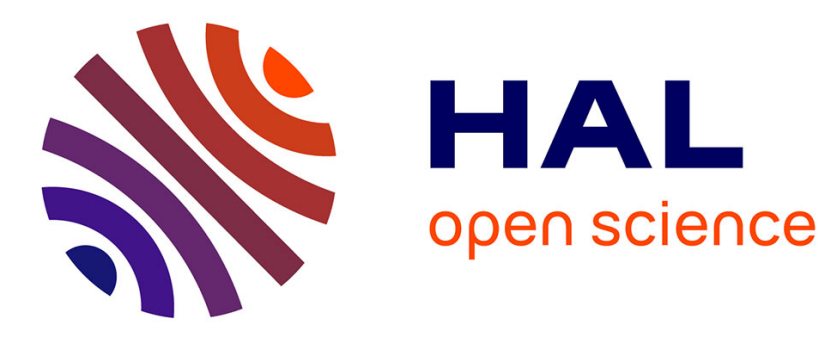

\title{
Distinct clonal anomalies involving in acute myeloid leukemia at diagnosis and after bone marrow transplantation
}

Etienne Braekeleer, Nathalie Douet-Guilbert, Audrey Basinko, Marie-Josée Bris, Frédéric Morel, Christian Berthou, Claude Férec, Marc Braekeleer

\section{To cite this version:}

Etienne Braekeleer, Nathalie Douet-Guilbert, Audrey Basinko, Marie-Josée Bris, Frédéric Morel, et al.. Distinct clonal anomalies involving in acute myeloid leukemia at diagnosis and after bone marrow transplantation: Distinct RUNX1 anomalies in AML. Annals of Hematology, 2010, 89 (12), pp.12771281. 10.1007/s00277-010-0937-x . hal-00534543

\section{HAL Id: hal-00534543 \\ https://hal.science/hal-00534543}

Submitted on 10 Nov 2010

HAL is a multi-disciplinary open access archive for the deposit and dissemination of scientific research documents, whether they are published or not. The documents may come from teaching and research institutions in France or abroad, or from public or private research centers.
L'archive ouverte pluridisciplinaire HAL, est destinée au dépôt et à la diffusion de documents scientifiques de niveau recherche, publiés ou non, émanant des établissements d'enseignement et de recherche français ou étrangers, des laboratoires publics ou privés. 


\section{Editorial Manager(tm) for Annals of Hematology}

Manuscript Draft

Manuscript Number: AOHE-D-09-00526R1

Title: DISTINCT CLONAL ANOMALIES INVOLVING RUNX1 IN ACUTE MYELOID LEUKEMIA AT DIAGNOSIS AND AFTER BONE MARROW TRANSPLANTATION

Article Type: Letter to the Editor

Keywords: RUNX1; acute myeloblastic leukemia; deletion; chromosomal translocation

Corresponding Author: Prof Marc De Braekeleer,

Corresponding Author's Institution: Faculté de Médecine

First Author: Etienne De Braekeleer

Order of Authors: Etienne De Braekeleer; Nathalie Douet-Guilbert; Audrey Basinko; Marie-Josée Le Bris; Frédéric Morel; Christian Berthou; Claude Ferec; Marc De Braekeleer

Abstract: No abstract required

Response to Reviewers: ANSWERS TO THE REVIEWER

First major comment (association of 7q deletions and microdeletions of the RUNX1 gene): the discussion on this subject was limited to the association of 7q deletions and RUNX1 mutations (page 5).

Second major comment (other genes involved): we completed the paragraph by adding the 3 genes located in the interval between both BACs with a description of "our" candidate gene (page 5).

Third major comment (RUNX1 constitutively prone to breakage): indeed, as suggested by the reviewer, we think there was a pre-leukemic stem cell in which acquired RUNX1 alterations cooperated with preexisting lesions to result in full blown acute leukemia. This was added in the last paragraph pf the manuscript (page 6).

All three minor comments were taken care of. 


\section{DISTINCT CLONAL ANOMALIES INVOLVING RUNXI IN ACUTE MYELOID LEUKEMIA AT DIAGNOSIS AND AFTER BONE MARROW TRANSPLANTATION.}

Etienne De Braekeleer ${ }^{1,2,3}$, Nathalie Douet-Guilbert ${ }^{1,2,3}$, Audrey Basinko ${ }^{1,2,3}$, MarieJosée Le Bris $^{3}$, Frédéric Morel ${ }^{1,2,3}$, Christian Berthou ${ }^{1,4}$, Claude Férec ${ }^{1,2,5}$, Marc De Braekeleer $^{1,2,3}$

${ }^{1}$ Université de Brest, Faculté de Médecine et des Sciences de la Santé, Brest, France.

${ }^{2}$ Institut National de la Santé et de la Recherche Médicale (INSERM), U613, Brest.

${ }^{3}$ CHU Brest, Hôpital Morvan, Service de Cytogénétique, Cytologie et Biologie de la Reproduction, Brest.

${ }^{4}$ CHU Brest, Hôpital Morvan, Service d'Hématologie clinique, Brest.

${ }^{5}$ CHU Brest, Hôpital Morvan, Laboratoire de Génétique moléculaire et d'Histocompatibilité, Brest.

Running title: Distinct RUNX1 anomalies in AML

Corresponding author: Pr. Marc De Braekeleer

Laboratoire de Cytogénétique

Faculté de Médecine et des Sciences de la Santé

Université de Bretagne Occidentale

22, avenue Camille Desmoulins

CS 93837

F-29238 Brest cedex 3

France

Phone: $\quad+33(0) 298016476$

Fax: $\quad$ + $\quad 33(0) 298018189$

E-mail: marc.debraekeleer@univ-brest.fr 


\section{DISTINCT CLONAL ANOMALIES INVOLVING RUNX1 IN ACUTE MYELOID LEUKEMIA AT DIAGNOSIS AND AFTER BONE MARROW TRANSPLANTATION.}

\section{Dear Editor,}

The RUNX gene family includes three evolutionarily conserved genes (RUNX1, RUNX2 and RUNX3) encoding transcription factors involved in cell lineage differentiation during development and various forms of cancer [1]. RUNX1 gene (also known as AML1 PEBP2 $\alpha B$, or $C B F A 2)$, located in chromosome $21 \mathrm{q} 22.3$, is crucial for the establishment of definite hematopoiesis and the generation of hematopoietic stem cells in the embryo. RUNXI acts as a key regulator of hematopoiesis through the regulation of various hematopoietic genes [1-3].

RUNX1 impairment resulting from mutation, deletion, translocation or amplification is reported to contribute to the pathogenesis of acute leukemias [4]. We report here distinct clonal anomalies involving the RUNX1 gene occurring in the course of the disease in a patient with acute myeloblastic leukemia (AML).

This 51-year-old man was first seen in February 2006 because of persistent rhinitis and recurrent epistaxis. Physical examination showed no adenopathy or hepatosplenomegaly. The peripheral blood count revealed a leukocytosis of $8.6 \times 10^{9} / 1$ with $37 \%$ blasts, $12 \%$ neutrophils, $25 \%$ monocytes and promonocytes, a hemoglobin level of $10.1 \mathrm{~g} / 1$ and a platelet count of $105 \times 10^{9} / 1$. The bone marrow aspirate showed hypercellularity with $68 \%$ blasts positive for CD13, CD33, CD117, MPO and CD65. AML-M1 was diagnosed (FAB classification). The patient received induction chemotherapy according to the LAM2001 protocol (Idarubicin and Cytarabin) followed by re-induction because of chemoresistance at day 15. The patient also received central nervous system prophylaxis with intrathecal 
injections. A complete remission was obtained. An allogenic bone marrow transplantation aspirate revealed $54 \%$ blast cells whose morphology and immunophenotype (positive for CD13, CD33, CD34, CD117) appeared identical to the blasts at diagnosis. The patient received a second BMT in February 2007. A complete remission was obtained. An isolated cutaneous granulocytic sarcoma localized at the penis, with normal bone marrow morphology, was diagnosed in July 2008. Surgery followed by radiotherapy was applied. In November 2008, a gingival granulocytic sarcoma and a medullar relapse, with $45 \%$ blasts, were observed. Induction chemotherapy failed to obtain a remission, the sole result being a stabilization of the leukocytosis.

R-banded karyotypes were established from sequential bone marrow aspirate samples that had been cultured for 24 hours synchronized by FUdR. Fluorescence in situ hybridization (FISH) analyses were performed using whole chromosome painting (WCP) of chromosomes 3, 7, 11, 21, 22 and arm specific probes (PCP) 3p, 3q (QBIOgene ${ }^{\circ}$, Illkirch, France), telomeric probes of chromosome 3 (Abbott ${ }^{\circledR}$, Rungis, France) and locus specific identifier (LSI) MLL, BCR/ABL1, TEL/AML1 (Abbott $\left.{ }^{\circledR}\right)$ as well as bacterial artificial chromosome (BAC) clones RP11-13M6, RP11-198D7, RP11-434P20, RP11-91K9, RP11-245C23, RP11-12L14 located on the long arm of chromosome 3 (3q26.3) and BAC RP11-77G18 covering AML1.

At diagnosis, a sole abnormal clone was detected. Karyotype was interpreted as 46,XY,der(7)t(7;11)(q31;q14)[7]/46,XY[15].ish $\operatorname{der}(7)(\mathrm{WCP} 7+, \mathrm{MLL}+)$, resulting in partial monosomy $7 \mathrm{q}$ and partial trisomy $11 \mathrm{q}$ including trisomy $M L L$ without rearrangement (Table 1) (Figs 1-A \& 2-A). 
At $1^{\text {st }}$ relapse following the $1^{\text {st }}$ BMT (December 2006), conventional cytogenetics, completed 46,XY,t(3;11;22;21;ㄱ)(p13;q14;q12;q22;q26)[15]/46,XY[5].ish $\quad \mathrm{t}(3 ; 11 ; 22 ; 21 ; \underline{3})(\mathrm{WCP} 3+$, PCP3p+,PCP3q+;WCP11+,MLL+,WCP3+,PCP3p+;WCP22+,BCR+,WCP11+,MLL+; WCP21+,AML1+,WCP22+;WCP3+,PCP3p+,PCP3q+,AML1+) (Fig 1-B). No $\quad M L L$ amplification was detected by FISH. FISH with BAC clone (RP11-77G18) covering the RUNX1 gene showed one signal on der(21) and one signal on der(3) (Fig 2-B). Breakpoints on 3q occurred between RP11-434P20 and RP11-245C23 with deletion of RP11-91K9. This translocation disappeared; interphase FISH on cells from the penis granulocytic sarcoma (July 2008) showed three RUNX1 signals, presumably signing re-emergence of the translocation (Table 1).

FISH analyses using TEL/AML1 probe were performed retrospectively at diagnosis and all along the disease. They revealed an abnormal clone with RUNX1 deletion (undetected by banding techniques), distinct from the clone with $M L L$ amplification, present at diagnosis (Table 1) (Fig 2-A). With chemotherapy and BMT, this clone disappeared until July 2008 before being again observed in bone marrow cells 4 months before the $2^{\text {nd }}$ medullary relapse was evidenced (Table 1).

The $R U N X 1$ gene is known to be frequently deregulated in human leukemia through different mechanisms [4]. In the case reported here, at the time of AML diagnosis, an overlooked clone with $R U N X 1$ deletion was present. It coexisted with a partial monosomic $7 \mathrm{q} /$ trisomic $11 \mathrm{q}$ clone, consistently observed in AML. Although hemizygous loss of RUNX1 function is suspected to play a key role in the development of myelodysplastic syndrome/acute 
myeloblastic leukemia (MDS/AML) patients, it is not sufficient to develop overt leukemia and acquisition of additional genetic alterations is necessary $[5,6]$.

RUNX1 mutations were found to be significantly associated with monosomy 7 or partial deletion of the long arm of chromosome 7 in studies of MDS/AML patients [6, 7]. RUNX1 mutations were suggested to be the major factor to develop MDS/AML in conjunction with additional gene alterations belonging to the RTK-RAS signal transduction pathway [6]. Interestingly, in our case, RUNX1 deletion and 7q deletion did not occur in the same cells. However, an additional RUNX1 mutation could not be excluded.

At first relapse, none of the clones present at diagnosis was detected but the RUNX1 gene was rearranged in a complex $3 ; 21$ translocation involving five chromosomes. The $\mathrm{t}(3 ; 21)(\mathrm{q} 26 ; \mathrm{q} 22)$ is a recurrent abnormality in therapy-related AML, occurring primarily after treatment with topoisomerase II inhibitors [8]. Three genes at 3q26, EVII, MDS1 and EAP are known to be fused with $R U N X 1$ in the $(3 ; 21)$ translocation $[9,10]$. In our case, the breakpoint at $3 \mathrm{q} 26$ is 8 megabases distal to the EVI1-MDS1-EAP cluster, arguing for the involvement of another gene. Three genes have been mapped in the interval between RP11-434P20 and RP11245C23. These are KCNMB2, a calcium channel, WIG1, a wildtype p53-induced gene, and TBL1XR1, a transducin-beta-like 1 receptor 1 (http://www.ncbi.nlm.nih.gov/mapview/). WIG1 could be a good candidate to be fused with RUNX1 as it is located in the nucleus and contains three zinc finger domains and a putative nuclear localization signal. Unfortunately, no cells taken at first relapse were available for further cytogenetic and molecular studies to characterize this partner gene. 
This report raises the question of whether the RUNXI gene was constitutively prone to breakage in the patient. Whether there was a pre-leukemic stem cell in which acquired $R U N X 1$ alterations cooperated with pre-existing lesions to result in full blown acute leukemia remains hypothetical.

\section{References}

1. Ito Y (2004) Oncogenic potential of the RUNX gene family: 'overview'. Oncogene $23: 4198-4208$

2. Michaud J, Scott HS, Escher R (2003) AML1 interconnected pathways of leukemogenesis. Cancer Invest 21:105-136

3. Okuda T, van Deursen J, Hiebert SW, Grosveld G, Downing JR (1996) AML1, the target of multiple chromosomal translocations in human leukemia, is essential for normal fetal liver hematopoiesis. Cell 84:321-330

4. De Braekeleer E, Ferec C, De Braekeleer M (2009) RUNX1 translocations in malignant hemopathies. Anticancer Res 29:1031-1038

5. Osato M (2004) Point mutations in the RUNX1/AML1 gene: another actor in RUNX leukemia. Oncogene 23:4284-4296

6. Niimi H, Harada H, Harada Y, Ding Y, Imagawa J, Inaba T, Kyo T, Kimura A (2006) Hyperactivation of the RAS signaling pathway in myelodysplastic syndrome with AML1/RUNX1 point mutations. Leukemia 20:635-644 
7. Christiansen DH, Andersen MK, Pedersen-Bjergaard J (2004) Mutations of AML1 are common in therapy-related myelodysplasia following therapy with alkylating agents and are significantly associated with deletion or loss of chromosome arm 7q and with subsequent leukemic transformation. Blood 104:1474-1481

8. Nucifora G, Birn DJ, Espinosa RI, Erickson P, Le Beau MM, Roulston D, McKeithan TW, Drabkin H, Rowley JD (1993) Involvement of the $A M L 1$ gene in the $\mathrm{t}(3 ; 21)$ in therapy-related leukemia and in chronic myeloid leukemia in blast crisis. Blood $81: 2728-2734$

9. Nucifora G, Begy CR, Kobayashi H, Roulston D, Claxton D, Pedersen-Bjergaard J, Parganas E, Ihle JN, Rowley JD (1994) Consistent intergenic splicing and production of multiple transcripts between $A M L 1$ at $21 \mathrm{q} 22$ and unrelated genes at $3 \mathrm{q} 26$ in (3;21)(q26;q22) translocations. Proc Natl Acad Sci USA 91:4004-4008

10. De Braekeleer E, Douet-Guilbert N, Le Bris MJ, Morel F, De Braekeleer M (2007) 3;21 translocation, trisomy 8 and duplication of the Philadelphia chromosome: a rare, but recurrent, cytogenetic pathway in blastic phase of chronic myeloid leukemia. Cancer Genet Cytogenet 179:159-161 
Table 1. Conventional and molecular cytogenetic results obtained during the course of the disease.

\begin{tabular}{|c|c|c|c|}
\hline Dates & Disease stage & Conventional cytogenetics & FISH \\
\hline February 2006 & Diagnosis & $\begin{array}{l}\text { BM: 46,XY,der(7)t(7;11)(q31;q14)[7]/ } \\
46, X Y[15]\end{array}$ & $\begin{array}{l}\text { M: } 3 \text { MLL \& } 2 \text { AML1 signals (32\%) } \\
\text { M: } 2 \text { MLL \& } 1 \text { AML1 signal }(8 \%) \\
\text { I: } 2 \text { MLL \& } 1 \text { AML1 signal }(14.5 \%)\end{array}$ \\
\hline March 2006 & Re-induction & BM: 46,XY[22] & $\begin{array}{l}\text { M: } 3 \text { MLL \& } 2 \text { AML1 signals }(2 \%) \\
\text { M: } 2 \text { MLL \& } 1 \text { AML1 signal }(12 \%) \\
\text { I: } 3 \text { MLL \& } 2 \text { AML1 signals }(1 \%) \\
\text { I: } 2 \text { MLL \& } 1 \text { AML1 signal }(10 \%)\end{array}$ \\
\hline July 2006 & $1^{\text {st }}$ complete remission & BM: ND & $\begin{array}{l}\text { M: } 2 \text { MLL \& } 2 \text { AML1 signals (100\%) } \\
\text { I: } 2 \text { MLL \& } 2 \text { AML1 signals }(100 \%)\end{array}$ \\
\hline October 2006 & After $1^{\text {st }}$ BMT & BM: ND & $\begin{array}{l}\text { M: } 2 \text { MLL \& } 2 \text { AML1 signals (100\%) } \\
\text { I: } 2 \text { MLL \& } 2 \text { AML1 signals }(100 \%)\end{array}$ \\
\hline December 2006 & $1^{\text {st }}$ relapse & $\begin{array}{l}\text { BM: 46,XY,t( } 3 ; 11 ; 22 ; 21 ; \underline{3})(\mathrm{p} 13 ; \mathrm{q} 14 ; \\
\mathrm{q} 12 ; \mathrm{q} 22 ; \underline{\mathrm{q} 26})[15] / 46, \mathrm{XY}[5]\end{array}$ & M: 2 MLL \& 3 AML1 signals (75\%) \\
\hline March 2007 & After $2^{\text {nd }} B M T$ & BM: ND & $\begin{array}{l}\text { M: } 2 \text { MLL \& } 2 \text { AML1 signals (100\%) } \\
\text { I: } 2 \text { MLL \& } 2 \text { AML1 signals }(100 \%)\end{array}$ \\
\hline June 2007 & $2^{\text {nd }}$ complete remission & BM: 46,XY[21] & $\begin{array}{l}\text { M: } 2 \text { MLL \& } 2 \text { AML1 signals (100\%) } \\
\text { I: } 2 \text { MLL \& } 2 \text { AML1 signals }(100 \%)\end{array}$ \\
\hline October 2007 & $2^{\text {nd }}$ complete remission & BM: 46,XY[21] & $\begin{array}{l}\text { M: } 2 \text { MLL \& } 2 \text { AML1 signals (100\%) } \\
\text { I: } 2 \text { MLL \& } 2 \text { AML1 signals }(100 \%)\end{array}$ \\
\hline February 2008 & $2^{\text {nd }}$ complete remission & BM: 46,XY[21] & $\begin{array}{l}\text { M: } 2 \text { MLL \& } 2 \text { AML1 signals (100\%) } \\
\text { I: } 2 \text { MLL \& } 2 \text { AML1 signals }(100 \%)\end{array}$ \\
\hline July 2008 & Granulocytic sarcoma & GS: no metaphases & I: 2 MLL \& 3 AML1 signals (58\%) \\
\hline July 2008 & & BM: 46,XY[50] & $\begin{array}{l}\text { M: } 2 \text { MLL \& } 2 \text { AML1 signals (100\%) } \\
\text { I: } 2 \text { MLL \& } 1 \text { AML1 signal }(7 \%)\end{array}$ \\
\hline November 2008 & $2^{\text {nd }}$ medullary relapse & ND & ND \\
\hline
\end{tabular}


BM: bone marrow

GS: granulocytic sarcoma

M: metaphase

I: interphase

ND: not done

BMT: bone marrow transplantation 


\section{LEGENDS TO THE FIGURES}

Figure 1. Conventional cytogenetics
A. Partial R-banded karyotype at diagnosis showing $\operatorname{der}(7) \mathrm{t}(7 ; 11)(\mathrm{q} 31 ; \mathrm{q} 14)$
B. R-banded karyotype at first relapse following the first BMT:

46,XY,t( $3 ; 11 ; 22 ; 21 ; \underline{3})(\mathrm{p} 13 ; \mathrm{q} 14 ; \mathrm{q} 12 ; \mathrm{q} 22 ; \mathrm{q} 26)$

Figure 2. Fluorescence in situ hybridization
A. FISH at diagnosis with LSI MLL dual color and TEL/AML1 ES dual color (Green/Orange) revealing two distinct clones (left nucleus is trisomic for 11q and right nucleus is deleted for $R U N X 1$ ).
B. FISH at first relapse following the first BMT with BAC RP11-13M6 (orange) and BAC RP11-77G18 (green) showing disruption of $A M L 1$ by $\mathrm{t}(3 ; 21)$. 
1

2

3

4

5

8

10

11

12

13

14

15

16

17

18

19

20

21

22

23

24

25

26

27

28

29

30

31

32

33

34

35

36

37

38

39

40

41

42

43

44

45

46

47

48

49

50

51

52

53

54

55

56

57

58

59

60

61

62

63

A

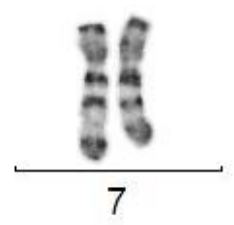

B
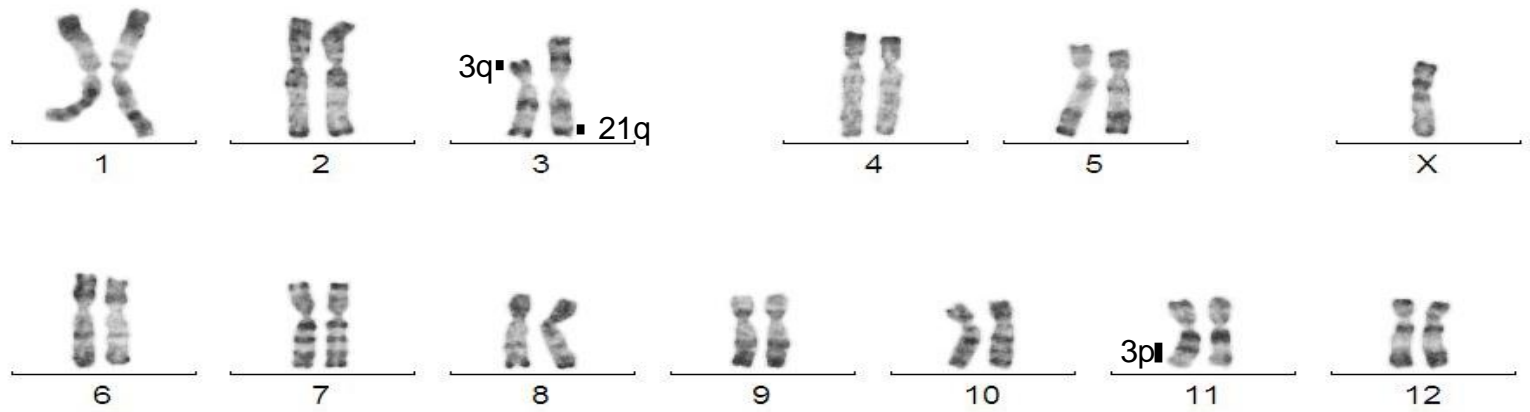

$\frac{3 p \mathbf{s} 8}{11}$
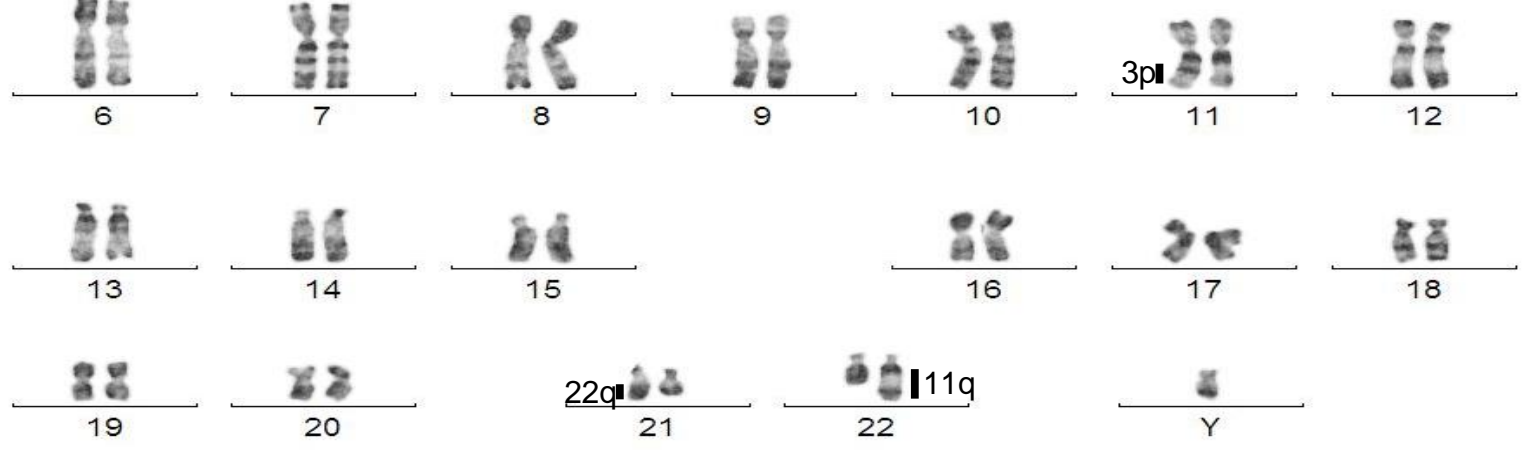
A

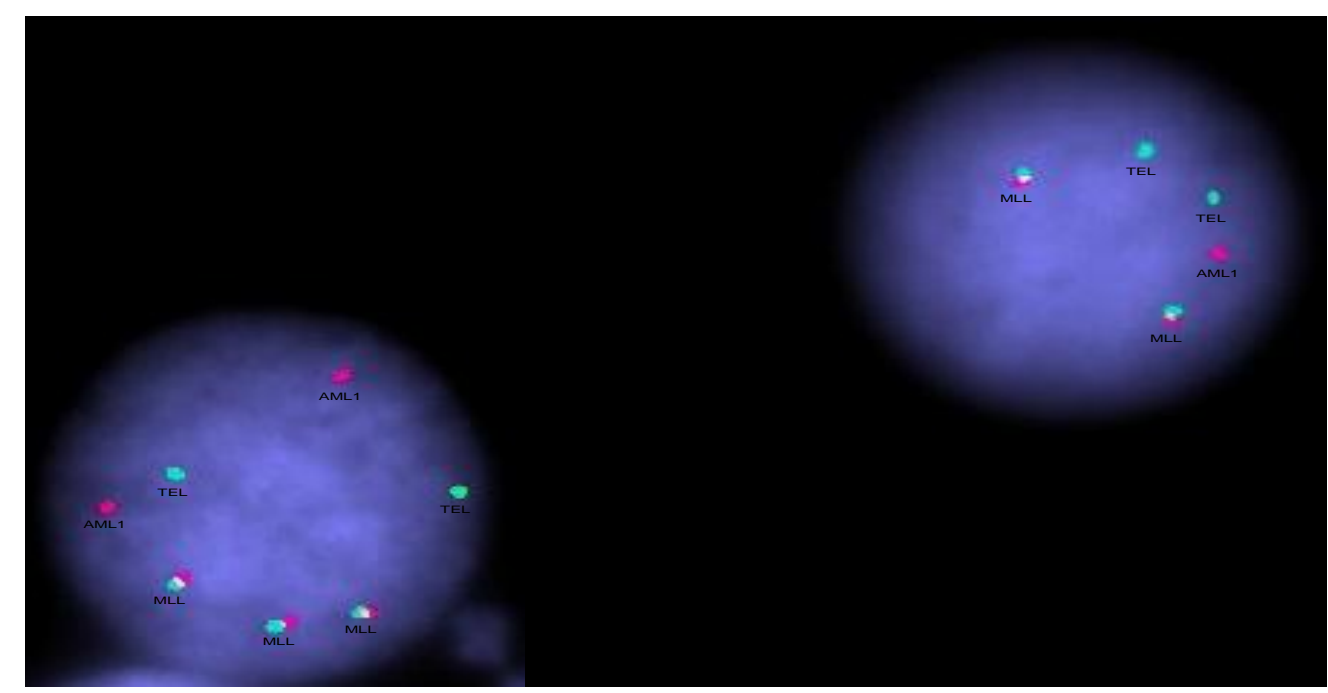

B

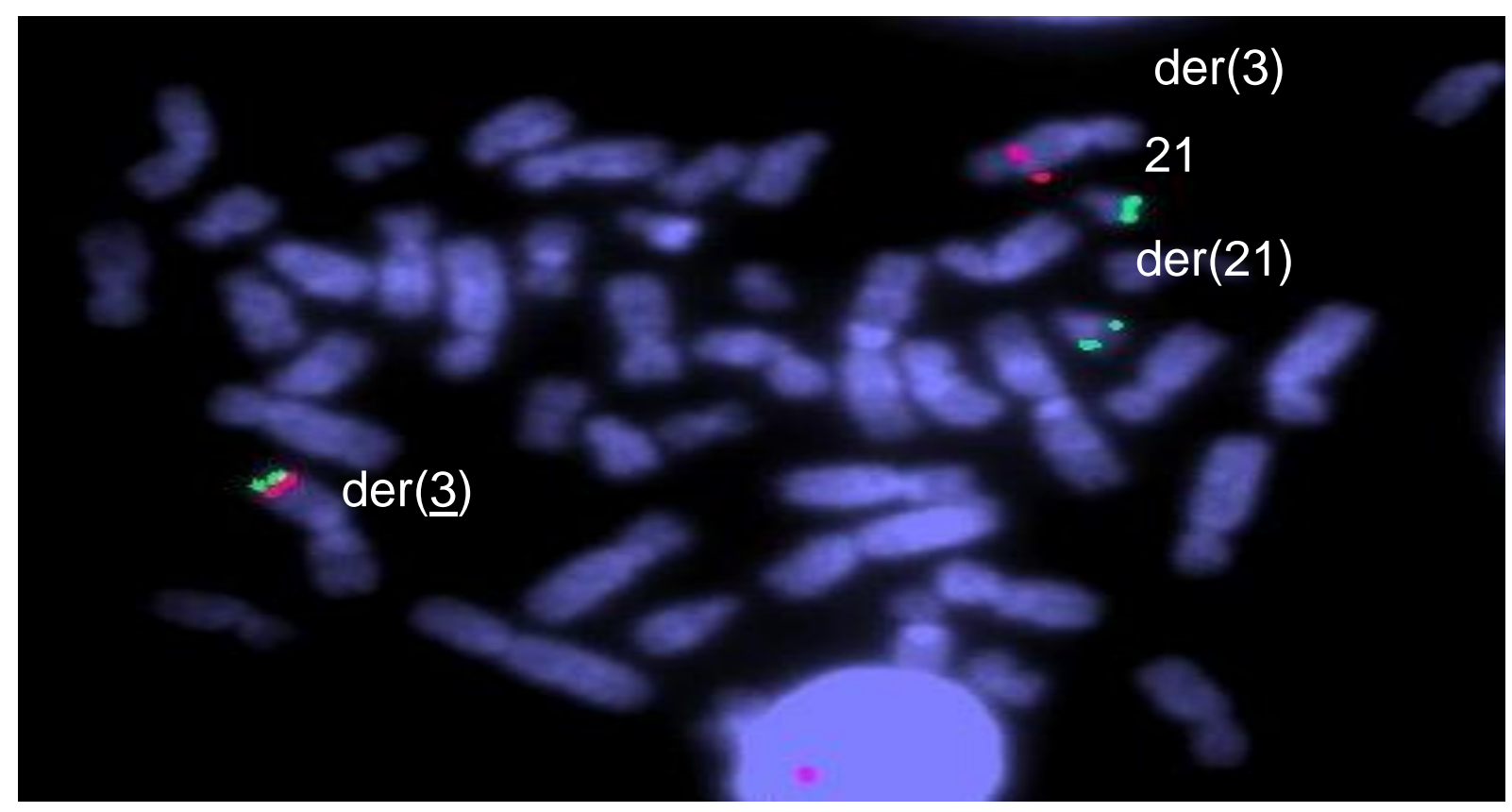


*Conflict of interest
Click here to downloa

Click here to download Conflict of interest: conflictofinterestdisclosureform.pdf 